\title{
Legal Perspective of the Internet Hoax
}

\author{
B Pratama ${ }^{1}$, Mutiara ${ }^{2}$, and M F Broto ${ }^{3}$ \\ ${ }^{1}$ Faculty of Humanities, Universitas Bina Nusantara, Jakarta, Indonesia \\ ${ }^{2,3}$ Law Department, Universitas Terbuka Indonesia, Banten, Indonesia \\ ${ }^{1}$ bptama@binus.ac.id
}

\begin{abstract}
The hoax is a global issue that must be face by many countries today. Hoaxes does not recognize the condition of a country whether the country is developed, developing or least developed country. As long as a country is connected by an Internet network and have many users on social media, hoax issues are inevitable, this condition brought many countries to the same level playing field with different set of readiness. The urgency to address hoax issues, has led this paper to examine the effectiveness of regulation as a safety fence to regulate informational rights. In so, arising basic question about what is hoax, and how to regulate it? The aim of this research is to analyzeregulation regarding hoax. This research is using doctrinal method with conceptual, theoretical, and comparative approaches. We found some of interesting funding, such as: terminology discourse, policy approach, and influenced factors as an actor of information diffusions. With this paper findings, we hope that hoax issue can be regulate more effective in the future.
\end{abstract}

\section{Keywords: Hoax, Information, Country}

\section{INTRODUCTION}

In the midst of free flow of information raised the question of the truth. Unfortunately, there is also negative information that contains false or libel news, hate speech and others fake news. For similarity of terms, the negative information referred in this paper is a hoax. The problem of hoax is not only a national problem, but also global problem. Therefore, the handling of hoax issue cannot be done partially. With the nature of the Internet that runs through the borders of the country, the distribution of information running on the Internet becomes complex than other conventional issues [1]. The most important things to consider from hoax problems on the Internet are the excesses that have a high destructive power, able to change the view of a society, and twisting facts, unlike another media.

Another facet in the hoax problem is numerous information channels such as websites, social media, chat rooms, and discussion group forums. This convergence sometimes made problems to capture the real phenomenon. To deal with a hoax, the common thinking is to answer type of information itself, then the legal prescription can be generated from that fact and from the information channels to define locus and tempus. But sometimes, the fact becomes blurred, because the politician running the issue. In 2013-2014 during Indonesia presidential election between Prabowo and Jokowi hoax are widely circulated on the Internet. Later in 2016 on Jakarta Guvnor election the hoax also widely spread. This condition shown 
that Internet is a powerful tool to manage public opinion. Luckily, hoax issue not only happen in developing country like Indonesia, but also occur in developed country like U.S in 2016 during presidential election between Donald Trump and Hillary Clinton. Even allegedly at the time of the US presidential election some social media companies like Facebook helped to play certain issues [2].

Based on Telecommunication Society (Mastel) survey in 2017, top three of hoax content are:(1) politics, (2) ethnic group, race, religion and inter-group (in Indonesian terms is SARA), and (3) health. [3] The weight political content in a hoax news cannot be denied anymore [4]. To respond hoaxes phenomenon, Indonesian National Police (POLRI) try to counteract the hoax information [5]. But with the abundance of hoax information on the Internet, sometimes this measure is failing to block the hoaxes. It's because some of the hoax news are widely spread by the computer machine, not human and the hoaxes issue are still remains on the Internet. As said on the previous section, that hoax is not particularly national problems, this paper tried to answer the basic question of what is a hoax, and how to regulate it? The above issues will be answered in a legal perspective.

\section{METHOD}

The research method used in this paper is legal research method, principally, they are there type of legal research, namely: doctrinal, empirical or socio-legal (non-doctrinal), [6] and comparative. In the development of science, to obtain a high degree of truth, it is necessary to use mixed research method with an interdisciplinary approach. Based on the reason above, and the nature of the interdisciplinary on Internet context (cyber space), the legal perspective on this paper will also describe interdisciplinary with computer (IT) context.

As a legal research, the explanation of legal norms cannot be eliminated. To avoid the narrowness and the scope of legal norms (ius constitutum), then correspondence with legal norms in some countries will be done [7]. In addition to the legal norms, the sources of law and other sources related to the topics will be examined, in expected to describe hoaxes problems holistically [8]. The Internet search engine will be used to collect the data in order strengthening the fact and data [9]. Then the collected data will by systematized and analyzed in accordance with the needs of this paper.

\section{RESULT and DISCUSSIONS}

\subsection{Hoax Terminology}

According to Hunt Allcott, conceptually hoaxes can be divided as: 1) unintentional mistakes, 2) rumors, 3) conspiracy theories, 4) satire news, 5) misstatements of politicians, and 6) false or misleading reports.[10] In a study conducted by the European Union (EU), the exact terms to classifying negative news is "disinformation" terms. The reasons why the EU using disinformation rather than hoax or fake news, because other terms inadequate and misleading [11]. Using the terminology of disinformation, the EU argues that 6 type of hoax as proposed by Allcott are conceptually reachable by the definition.

If the terminology of hoax and disinformation is referred deeper, hoax terms are the fabrication of an improper/deceptive report. While disinformation is false information propagated to trick the truth [12]. With the broad concept of disinformation and to lay the legal, the exact terminology is disinformation compared to hoaxes as the genus of lying or misleading news terms. However, most commonterms is a hoax ratherthan disinformation.In 
relation to Internet hoax or electronic information, historically first appeared in 1988 followed with computer virus [13]. Before the Internet booms, the circulation of hoaxes on the Internet most likely harmful. Along with Internet user growth acceleration, circulation of hoaxes exponentially increased. In general circulation of a hoax method on the Internet was done by two models, namely by forwarding email to others with certain topics, and electronic newsletters. Through numerous devices to access the Internet and various form of information channel on the Internet also changed hoaxes transmission.

\subsubsection{Short Historyof Hoax}

In a historical perspective the first hoaxes regulation can be found in the United States in 1798 in the Sedition Act, which was born after the first amendment of the United States Constitution. The regulation is to protect the government from the suit by its citizens by spreading false news (fake news). This rule reasoning is based the protection of public interest, this mean under certain circumstances the government can issue false news [14]. To describe the impact of hoaxes, the referral of fraud cases in the British stock exchange in 1814. The cases occur during the war between England and France. By making news of Napoleon Bonaparte death, the stock exchange responded positively in the morning, but on the afternoon was known that Bonaparte death is fake, then the stock exchange went down. Behind the hoaxes story, Andrew Cochrane-Johnstone with the speculator was take an advantage of British government 1 million Pound sterling stock spike [15]. The important from the British Stock Exchange Fraud in 1814, is the actors who had a benefit from the existence of hoaxes and the punishment to someone who had profited from a lie.

In some types of hoax can even end up to the death of a person's life, in so in the U.S Criminal Code the threat of imprisonment and/or punitive damages is regulated. Interestingly from the Hoax regulation in the United States, the law also regulates the impact of hoaxes. If a news hoax leads to the loss of a person's life, the punishment becomes more severe.US Supreme Court Justice Oliver Wendell Holmes, argue that the concept of free speech begins since 1912 on the flow of information on radio and mass media. According to Levine, Holmes observations are the forerunner of the distribution of information to the public, in which the rules of negative information (misleading information) was set for the first time in 1912 with the issuance of a law on radio [16]. However, the content of the information conveyed, US law has determined the type of information, which has a form of protection of the first constitutional amendment of the United States in 1791. The first amendment of the United States Constitution aims to protect right of expression, political rights and press rights as one of the pillars of democracy, then the aspects of information forms including commercial information are also governed by the American law. That is, the regulation on the rights of expression not only about the political, social, and cultural aspects, but also the economic aspects. Therefore, the regulation of hoax as a special part of the right of informationcommonly inserted on a country constitution.

\subsubsection{Code is Law}

Lawrence Lessig argue, to regulate cyber space or Internet cannot only use juridical approach, but needs to used system approach, namely: law, norms, architecture, and market [17]. 
Table 1. Cyber Law Influence Factor.

\begin{tabular}{ll}
\hline \multicolumn{1}{c}{ Component } & \multicolumn{1}{c}{ Description } \\
\hline Norms & Behaviors and value in society \\
Market & Driven market in information \\
Technology Architecture & Technological design \\
Law & How the law regulates? \\
\hline
\end{tabular}

Referring to Lessig's argument, the condition of rule in the cyber space necessarily can be evaluated. If there is a weak component inside, then must be strengthened. The regulation mapping on hoax that can be draw based on the current condition of Indonesia is as follows:

Table 2. Hoax Regulation and Condition.

\begin{tabular}{|c|c|c|}
\hline Component & Condition & Description \\
\hline Norms & Behavior shifting to information society & $\begin{array}{l}\text { They are some culture } \\
\text { shock }\end{array}$ \\
\hline Market & $\begin{array}{l}\text { - New in advertising business model; } \\
\text { - Social media business mode (trading like, } \\
\text { subscriber, follower, etc.); } \\
\text { - Public figure needs created new opportunity } \\
\text { and new market. }\end{array}$ & $\begin{array}{l}\text { The dynamic of the market } \\
\text { cannot easily catch, one of } \\
\text { the best solutions is to } \\
\text { create multi-stakeholder } \\
\text { code of practice }\end{array}$ \\
\hline Technology & - Censorship system; & In some circumstance, \\
\hline Architecture & $\begin{array}{l}\text { - Fact checking or machine learning system; } \\
\text { - Report and take down system. }\end{array}$ & $\begin{array}{l}\text { computer system cannot } \\
\text { retain information free- } \\
\text { flow. }\end{array}$ \\
\hline Laws & $\begin{array}{l}\text { - Regulation on information and electronic } \\
\text { transaction; } \\
\text { - Regulation on public disclose information; } \\
\text { - Regulation on press; } \\
\text { - Regulation on broadcasting; } \\
\text { - Regulation on consumer protection; } \\
\text { - Regulation on general election. }\end{array}$ & $\begin{array}{l}\text { All of regulation not } \\
\text { regulate the impact of } \\
\text { hoax's and needs to } \\
\text { specify the type of hoax } \\
\text { (between disinformation } \\
\text { and misinformation) }\end{array}$ \\
\hline
\end{tabular}

At the legislation level, in general hoax is regulated by generalizing three related forms: consumer loss, ethics, and ethnicity, religion, race and interclass (SARA). Referring to the many-formed hoaxes and their use commonly runs by public figure and politician. To such condition, the needs for hoaxes regulation for public figure and for the election law become necessity.

\subsection{Hoax in Juridical Perspectives}

Freedom of expression in Indonesia is regulated in article 28 of the 1945 Constitution, with the provision: freedom of association, assembly and expression of opinion both orally and in writing stipulated by law. With the provisions on the Constitution, freedom of expression was governed by law, this means they are some condition that the government may prohibit the form of expression or otherwise. Historically, within second amendment of the constitution is 
precepted the right of information which becomes one part of integral part on freedom of expression.

The derivative rules of freedom of information, among others: information and electronic transaction (ITE Law) and public disclose information act. Before the existence of these two laws, the press and broadcasting law was prearranged, but the law did not specify detail of hoaxes type. From a series of the laws, only the ITE law that regulates more specific on hoaxes, inter alia: decency, consumer loss and racial intolerance. However, comparing with the arrangement in the United States, Indonesian law does not regulate the impact of the hoax to severity of the punishment.

As an anticipative step to overcome the hoax's issue, Indonesian government established the National Cyber Agency. In addition, another step taken by the Minister of Communication and Informatics is to introduce legal sanctions in the form of fines to social media such as Facebook or Twitter, if they let news or hoax information circulate in their social media.

\subsubsection{Information Concept, Distribution and Legal Responsibility}

Conceptually, information is a domain of communication science in which among them learn about the distribution and effectiveness of information [18]. With the advent of digital media of the Internet, the ways of communicating have changed. Inside information also mingling other legal regime, namely intellectual property[19]. This is why some of the scholars explain information as a multi-faceted concept. However, the form of electronic communication has a space between the public and private [20]. On the diffusion information in a space, they are different legal consequences inside it. For example, the term 'public', on the or public space is very important to be explain by the provider of electronic system, in so the user have knowledge what type of sphere they enter, by using the social media platform. This information is expected to increase awareness on user when they use their information including collecting, processing, and transmitting.

In relation to information, press personnel also played important role. The position of the press as the legal subject of information and news providers has different legal consequences. The inherent of these differencessolely based on an authority or position as a news searcher. Chairman of the Press Council, Yosef Adi Prasetyo distinguishes two types of information, namely: (1) media info, which means a piece of messages or a collection of initial messages submitted by someone and received by a media institution, (2) news, collection of media info that has been checked the truth and verified before submitted to the public/society [21].

Table 3. Differencesbetween Press andSocial Media.

\begin{tabular}{lll}
\hline & \multicolumn{1}{c}{ Press Product } & Social Media Product \\
\hline Output & $\begin{array}{l}\text { News } \\
\text { Journalist } \\
\text { competency }\end{array}$ & $\begin{array}{l}\text { Information } \\
\text { Anybody }\end{array}$ \\
Editorial teams, & Individual \\
and standardize & Waterfall system & $\mathrm{n} / \mathrm{a}$ \\
Responsibility & $\begin{array}{l}\text { Code of } \\
\text { Journalistic }\end{array}$ & $\mathrm{n}$ \\
Batasan & $\begin{array}{l}\text { Corporation } \\
\text { Person in charge } \\
\text { by position }\end{array}$ & $\begin{array}{l}\text { Individual } \\
\text { Can be faked }\end{array}$ \\
Identity & &
\end{tabular}




\begin{tabular}{lll}
$\begin{array}{l}\text { Way } \\
\text { messaging }\end{array}$ & $\begin{array}{l}\text { Print, online, TV } \\
\text { and Radio }\end{array}$ & $\begin{array}{l}\text { Social media (Twitter, } \\
\text { Facebook, WhatsApp, Line, } \\
\text { Path, Instagram) } \\
\text { Can be official, or } \\
\text { unofficial, or fake }\end{array}$ \\
\hline
\end{tabular}

Sources: Yosef Adi Prasetyo, 2017.

Based on the table above, can be seen that the process and form of accountability between the press and the common person and non-press are different. Legal responsibility can be clearly seen on the waterfall responsibility system. The waterfall system is known as the Belgian system that imposes liability to the author, or publisher, or printer, if it cannot be submitted to the court of one of the parties on a graded basis if absent [22]. Depart from the system of accountability of the press that implements graded of accountability, surely must applied also to the provider of electronic system. For example, the burden of accountability to Facebook or Twitter as a provider of communication services as conducted in Germany [23]. In addition to imposed criminal sanctions on communications service providers, Malaysia and India instead impose criminal sanctions on WhatsApp's group admin allowing its members to spread hoax news [24]. Related to the different types of information disseminated by a person, then the concept of law should be observed who is the sender of the information and what kinds of media that had been used to deliver the information. The clarity of the intention and the person who transmit the information becomes necessary to impose legal liability to him if it is spreading the hoax.

\subsubsection{Some Action in Fighting Hoax}

To fight hoaxes, the Information Society Project and the Floyd Abrams Institute for Freedom of Expression recommend four components, namely: (1) accreditation system, (2) market incentive, (3) technological design, (4) law [25].Each side of component above, should had part of responsibility by helping to reduce the circulation of the hoax, but in reality, between each component is still running individually. In the field of technology for example: some technological approaches used by Facebook by using fact-checker [26] technology with the help of machine learning [27]. Another step taken by the social media IT company Twitter is to detect the Bot system used by Twitter users, if it is known there are Twitter users who use their account for suspicious activity then Twitter will block it [28]. In addition, Twitter also received complaints from its users when reporting the use of Twitter account to spread the hoax [29].

Another effort that can be applied from the market side is to create a CSR for IT companies to combat hoaxes. Facebook founder Mark Zuckerberg tried to perform this method by starting the community programs as a form of corporate Facebook accountability [30]. Another thing that can be done for example by giving incentives to IT companies who are trying to combat hoax. With market approach and share responsibility among multistakeholder, fighting hoax will be effective.

\section{CONCLUSION}

Fake news and others false information terms are more precise to use disinformation terms, but common terms frequently used is hoax. In spite of discrepancy, disinformation is genus of negative information. In legal perspective, determining general(genus)terms and specifics (specia) terms is very important to capture legal phenomenon. In order to regulate hoaxes, 
Code is Law can be used, by partially imposed legal responsibility to all of actors in digital media, like social media company. By this concept, burden of responsibility not only for the user, but divide to all related party. Beside responsibility to a media social or platform company, creating some kind incentive to them can balanced the imposition of rights. They are many ways to create market incentive, but the real objective must to maintain is a multistakeholder or multi-actor responsibility to fight hoax on the Internet.

\section{REFERENCES}

[1] H. Djamal and A. Fachruddin, Dasar-Dasar Penyiaran. Jakarta: Kencana Prenadamedia, 2011.

[2] I. Lapowsky, "Here's How Facebook Actually Wont Trump The Presidency," 2016. .

[3] Mastel, "Survei Mastel tentang Wabah Hoax Nasional," 2017.

[4] M. P. Fauzi, "Lebih dari 90\% Berita Hoax di Indonesia Bermuatan Politik," Okezone, 2017.

[Online].

Available: https://techno.okezone.com/read/2017/02/13/207/1616892/lebih-dari-90-berita-hoaxdi-indonesia-bermuatan-politikLyons.

[5] Majalah ICT, "Perang Melawan Hoax," Majalah ICT, 2017. [Online]. Available: http://www.majalahict.com/perang-melawan-hoax-1/.

[6] S. Wignjosoebroto, Ragam-Ragam Penelitian Hukum in Metode Penelitian Hukum Konstelasi dan Refleksi. Jakarta: Yayasan Pustaka Obor, 2011.

[7] J. Hage, "Comparative Law as Method and the Method of Comparative Law," SSRN Electron. J., 2014.

[8] C. Martin, P. Hazelton, P. R. Jarrett, M. McCluer, and M. Whisner, Washington Legal Researcher's Deskbook. Seattle: Washington Law School Foundation, 1994.

[9] R. L. Miller, Online Legal Research. Ohio: South-Western Publishing, 2010.

[10] H. Allcott and M. Gentzkow, "Social Media and Fake News in the 2016 Election," National Bureau of Economic Research, Cambridge, MA, Jan. 2017.

[11] European Commission, A Multi-dimensional approach to disinformation. Brussels: Directorate-General for Communications Networks Content and Technology, 2018.

[12] W. Meriam, "Online Dictionary Online 2018 Disinformation," 2018. .

[13] H. B. Dunn and C. A. Allen, "Rumors, Urban Legends and Internet Hoaxes Proceeding of the Annual Meeting of the Association of Collegiate Marketing Educators," Proceeding of the Annual Meeting of the Association of Collegiate Marketing Educators, 2005. .

[14] E. Volokh, “The Volokh Conspiracy," Washington Post, 2016. [Online]. Available: https://www.washingtonpost.com/news/volokhconspiracy/?noredirect $=$ on\&utm_term $=$.dc011961fle4.

[15] J. Pollard, Secret Britain, the Hidden Bits of Our History. London: John Murray, 2009.

[16] J. A. Levine, "History and Analysis of the Federal Communication Commission's Response to Radio Broadcast Hoaxes," Fed. Commun. Law J., vol. 52, no. 2, pp. 274 76, 2000.

[17] L. Lessig, Code Iaw. New York: Perseus Books Group, 2006.

[18] M. M. Kraidy, "The Internet as a Mass Communication Medium Journalism and Mass Communication," p. 5, 2008.

[19] B. Pratama, "Legal Prescription on Virtual Property and Its Rights," J. Phys. Conf. Ser., vol. 801, p. 12090, Jan. 2017.

[20] D. Holmes, Communication Theory, Media, Technology and Society. The Great Britain: Sage Publication, 2005. 
[21] Y. A. Prasetyo, Merunut Media Hoax dan Upaya Melawannya. Jakarta, 2017.

[22] A. Murani, "Aspek Hukum dan Tanggung Jawab Pers," J. Ilmu Komun., vol. 1, pp. 34-5, 2013.

[23] M. A. Gunawan, "Begini Cara Jerman Perangi Hoax dan Hate Speech," Detik, 2017. [Online]. Available: https://inet.detik.com/law-and-policy/d-3447048/begini-carajerman-perangi-hoax-dan-hate-speech.

[24] Varanasi, "Now, offensive WhatsApp posts can land group admin in jail," Bussines Today, 2017. [Online]. Available: https://www.businesstoday.in/current/economypolitics/offensive-whatsapp-posts-can-land-group-admin-in-jail/story/250425.html.

[25] Abrams Institute, "The Information Society Project and the Floyd Abrams Institute 2017," in Fighting Fake News Workshop Report, 2017.

[26] R. LeFebvre, "Facebook is stepping up its fight against fake news," 2018. .

[27] Tessa Lyons, "Increasing Our Efforts to Fight False News," Facebook Newsroom, 2018. [Online]. Available: https://newsroom.fb.com/news/2018/06/increasing-ourefforts-to-fight-false-news/.

[28] C. Crowell, "Our approach to bots and misinformation," Blog Twitter, 2017. [Online]. Available: https://blog.twitter.com/en_us/topics/company/2017/Our-Approach-BotsMisinformation.html.

[29] A. Robertson, "Twitter says it did everything it could to fight YouTube shooting hoaxes," The Verge, 2018. [Online]. Available: https://www.theverge.com/2018/4/5/17203862/twitter-youtube-shooting-hoaxmisinformation-strategy-defense.

[30] K. Rider and D. Murakami Wood, "Condemned to connection? Network communitarianism in Mark Zuckerberg's 'Facebook Manifesto,"” New Media Soc., p. 146144481880477 , Oct. 2018. 